\title{
Diacronie
}

Studi di Storia Contemporanea

$\mathrm{N}^{\circ} 19,3$ | 2014

Miscellaneo

\section{Beyond the iron curtain of historiography, between party canon and scholarly standard}

A theoretical and methodological approach to the analysis of East European national-communist historiographies: the case of Romania

\section{Francesco Zavatti}

\section{(2) OpenEdition}

Journals

Electronic version

URL: http://journals.openedition.org/diacronie/1613

DOI: 10.4000/diacronie. 1613

ISSN: 2038-0925

Publisher

Association culturelle Diacronie

\section{Electronic reference}

Francesco Zavatti, «Beyond the iron curtain of historiography, between party canon and scholarly standard », Diacronie [Online], N 19, 3 | 2014, document 5, Online since 01 July 2014, connection on 21 April 2019. URL : http://journals.openedition.org/diacronie/1613; DOI : 10.4000/diacronie.1613 


\section{Diacronie}

\section{Beyond the iron curtain of historiography,}

between party canon and scholarly standard

\section{A theoretical and methodological approach to the analysis of East European national-communist historiographies: the case of Romania}

Francesco ZAVATTI *

This paper aims at elaborating a new theoretical framework and a new methodology in order to identify the location of history discipline endorsed by the East European communist regimes between scholarly production and propaganda. The case study considered is the historiography produced by the History Institute of the Romanian Communist Party (Isisp) during the Ceausescu regime (1965-1989). This highly ideological, but still polymorphic historiography is placed into the context of the $19^{\text {th }}$ and $20^{\text {th }}$ centuries' professionalization of history in Europe. Since historiography has been the main mean to develop nationalist messages, this paper is also a contribution to the study of nationalism. Since history-writing is a myth-breaker but also a (national) myths-maker, the theory considers that the Isisp historians were elaborating an academic, scholarly standard while performing the mandatory metanarrative canon imposed by the communist Party, creating a double-set of coherence, for the party and for their own profession. The theory implies also a methodology of analysis which integrates the study of the history-writings, considered in diachronical perspective, together with the collective biographies of Isisp and of its historians. 
- "Ma cac in ideologie acum!"

[ "I don't give a damn about ideology now!']

- Party Representative of the control commission for ideology in the movie Tales from the

Golden Age (2009)

\section{Introduction}

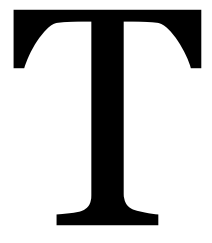

his paper aims at identifying the location of history discipline endorsed by the East European communist regimes between scholarly production and propaganda. The case study considered is the historiography ${ }^{2}$ produced by the History Institute of the Romanian Communist Party (from here on, "Isisp") during the Ceausescu national-communist regime (1965-1989). The location of this historiography between scholarly production and propaganda is identified by 1) a theoretical approach which considers history discipline as literature influenced by ideology, and performed by textual and non-textual practices; 2) a multi-faceted methodology of analysis which offers an understanding of this historiography and of its scholarly, political, domestic and international context.

How is it possible to trace down the historiographies of communist East European countries on this imaginary line between propaganda and scholarly writings? My hypothesis is that, by a merged analysis of the power directives, the power relationships and the practices of (professional) survival occurring among historians of the same milieu, as well as the narratives they produced, it is possible to deepen the understanding of the practices of history-writing itself, and, from there on, to depict a first sketch of the state of history-writing in communist Eastern Europe, at least in the case study considered - the historiography of the Romanian Communist Party. This first methodological step is intended to be a move towards a more ambitious project, namely the mapping of Eastern European historiographies during communist times, beyond mere phenomenology, towards a discourse on the nature of history discipline and its relationship with power3.

\footnotetext{
${ }^{1}$ MUNGIU, Cristian, Tales from the Golden Age, Romania, Mobra Films, 2009, 138'.

2 A terminological clarification: I refer to "historiography" to indicate the products of "historywriting" (synonym with "historical research", and "history"). "History-writing" is the discipline that produced the narratives of historiography, broadly defined, and which included textual and non-textual practices (see below).

3 Official historiographies in Eastern Europe presented several metanarrative canons developed by the historians, since East European countries during the cold war was divided in Warsaw Pact countries, non-aligned Yugoslavia, Hoxha's Albania, and Soviet Union. Those official
} 
This mapping contributes to the understanding of the different politics that generated those historiographies. It also offers the possibility to admit the vast archipelago of "organic intellectuals" communities of historians into the family of historiography in Europe. In this regard, it should be stressed that scholars did not take historiography produced by the communist parties beyond the Iron Curtain in serious consideration, and gave no real agency to institutes such as Isisp. For example, cultural anthropologist Katherine Verdery, which wrote a cornerstone volume about cultural politics in communist Romania, described the director of Isisp Ion Popescu-Puţuri as a "Party historian" 4 . With the same lack of deepening, historian Alexander Zub described the same director as "historian in service", and dedicated only few lines here and there to the Isisp Institute5. Neither the scholars who in the mid-seventies started to problematize this historiography, gave any scholarly value to it. For example, historian Vlad Georgescu fled the country in 1977, becoming a Radio Free Europe journalist, has not scrutinized the power relationships inside Isisp, giving its historians no real agency $^{6}$. But, since these latter performed their professional identity, they objectively had agency; and I aim at describing the complexities of this agency, filling the gap left in scholarly literature.

Being the majority of literature addressing national-communist historiography specifically addressed to the study of nationalism7 ${ }^{7}$, this paper stands also as a methodological contribution to the understanding of nationalism in historiography, developed by the combined analysis of historiography, of the personal biographies of the historians who wrote it and of the collective biography of the institution which hosted them.

\footnotetext{
historiographies are worth studying for the potential contribution to the understanding of Eastern European politics, and particularly for deconstructing culturally the history-based nationalism under communism meant at feeding international and interethnic conflicts.

4 VERDERY, Katherine, National Ideology under Socialism, cit., p. 355, note 35.

5 ZUB, Alexandru, Orizont închis. Istoriografia română sub dictatură, Iaşi, Institutul European, 2000, p. 174 and note 56.

${ }^{6}$ GEORGESCU, Vlad, Politică şi Istorie. Cazul comuniştilor români (1944-1977), Bucharest, Humanitas, p. 101. See also the very hard judgment given by Apostol Stan, which in his memories considered Isisp historians as mere propagandists, in STAN, Apostol, Istorie şi politică în România comunistă, Bucharest, Curtea Veche, 2010, pp. 276-278.

7 In this sense, I intend to develop the catchy metaphor "nation=narration" wrote by Homi Bhabha, which considers that the narration/nation has a double-time given by modernity: one given by nationalist pedagogy and another given by the everyday performance of the real nation. See BHABHA, Homi K. (ed.), Nation and Narration, London, Routledge, 1990, pp. 1-7, 291322.
} 


\section{A note on the political context (1948-1989)}

Historiography in communist Romania has been one of the most important cultural instruments in the search for legitimacy among the population. When it went to power (1948), the Communist Party was not sustained by the Romanian population, since Marxist-Leninist discourse was completely alien to the population, since this latter had been trained in national ideology since nineteenth century ${ }^{8}$. During the Stalinist period (1948-1956) the regime conserved its power by violence and repression, while culture was based on dogmatic Stalinist tenets9. After 1956, the destalinization begun with CPSU's twentieth congress represented a serious risk for party's secretary Gheorghe Gheorghiu-Dej and for Romanian political elite, which reacted to the process of destalinization playing out what Georges Haupt described as a «reaction to destalinization ${ }^{10}$. Romanian elite made all the necessary efforts to make Romania independent from the Soviet Union. The end of Stalinism coincided with the beginning of what has been defined by scholars as «national-communism»"11. It brought to the search for consensus and to focus on the discourse of the nation, and the bourgeois intellectuals were permitted to continue their interwar discourses on the nation, which had been interrupted by Stalinism. As the discourse on the nation in communist Romania was originated by political causes, so was its evolution: Ceaușescu, which succeeded to Gheorghiu-Dej in 1965, oriented and regimented Romanian intellectual life, and the world of historians with it, until December 1989. Isisp, founded in 1951, continued to exert its functions until February 1990, when it was disbanded, despite changes of names and of dimensions, and despite the changes in domestic and international political context.

\footnotetext{
8 VERDERY, Katherine, National Ideology and National Character in Interwar Romania, in VERDERY, Katherine, BANAC, Ivo (eds.), National character and national ideology in interwar Eastern Europe, New Haven, Yale Center For International and Area Studies, 1995, pp. 103-133.

9 'Historiography became an annex of the party's politics'. Source: Interview by the author with Şerban Papacostea [Bucharest, Romania; February 7, 2013]. See also VERDERY, Katherine, National Ideology under Socialism: Identity and Cultural Politics in Ceauşescu's Romania, Berkley, University of California Press, 1991.

${ }^{10}$ HAUPT, Georges, «La genèse du conflit soviéto-roumain», in Revue française de science politique, XVIII, 4/1968, pp. 669-684.

${ }^{11}$ Ibidem. See also TISMANEANU, Vladimir, Stalinism for All Seasons. A Political History of Romanian Communism, Berkley,University of California Press, 2003, pp. 32 et seq.
} 


\section{Theory: Between propaganda and scholarly history-writing}

Was the history institute of the Romanian Communist Party producing scholarly history-writings or propaganda? At first glance, one would be tempted to consider the issue useless and redundant, and simply label the Isisp as "propaganda institute". But, giving dialectics a chance, the understanding that results from this analysis would contribute substantially to the understanding of the relationships between politics and academia, and of the role of the historian as the performer of different canons and standards. A useful mean for the analysis of Isisp life and functioning is to analyse the tension between the metanarrative canon imposed by the Party to the historians and to their narratives, and the standard of the history discipline ${ }^{12}$ that those historians produced. It is here impossible to give a specific definition of standard, since there was (and still is) no international recognized standard, among historians for their own profession. There are rather set of textual practices retraceable in the narratives produced (i.e., structure of the inquiry, presence of notes and bibliography) as well as extra-textual ones, embodied in the functions of the historians and of the institutions ${ }^{13}$. These one will allow reaching a possible definition of standard.

The historians enrolled at the Institute operated in a protected and advantaged environment: they could consult restricted-access sources, while the Party hided or showed documents at its discretion. They were the only voices authorized to speak in a country were free debates belonged to the past and were no more allowed. By education, these historians were partly Party activists educated at the Party's school but mainly professional historians educated at the Universities of Bucharest, Iaşi and Cluj ${ }^{14}$.

\footnotetext{
${ }^{12}$ I borrow the idea of history-discipline's "standard" from PORCIANI, Ilaria, TOLLEBEEK, Jo (eds.), Setting the Standards. Institutions, Networks and Communities of National Historiography, New York, Palgrave MacMillan, 2012, pp. 3-23.

${ }^{13}$ It must be added that The Party displayed its power also enrolling historians and investing huge financial resources in Isisp, in its reviews and journals, and by subsidizing the presence of its historians at international conferences. Sources: ANIC, CC al PCR, Secţia Cancelarie, 9/1983; ANIC, CC al PCR, Secţia Propaganda şi Agitaţie; 9/1966, 3-8; 10/1978, 36, 44, 48-51, 74-79; 21/1979; 25/1980; 6/1982; A-6/23, 282-283; ANIC, Fondul familial Popescu-Puţuri, 54, 32-33. In two cases, Isisp had to withdraw its participation from international conferences by political decision: ANIC, CC al PCR, Fondul Isisp: A-5/10, 570-571; ANIC, CC al PCR, Secţia Propaganda şi Agitaţie, 11/1978 11-27.

14 A sample of fifty-eight Isisp historians is reported in ŞTEFANESCU, Ştefan, Enciclopedia Istoriografiă româneşti, Bucharest, Editura Ştiinţifica şi Enciclopedica, 1978. The author of this article built and conserves a database for those fifty-eight Isisp historians, listing for each historian: name, year of birth, city of birth, university attended, specialization, work experiences, years of enrolment in / dismissal from Isisp, main publications. A limitation of the
} 
Despite their educational background, graduated or nor, all of them were able to write history well, with inspiration and competence - they were good craftsmen, and the party recognized their ability to write history in party canon fashion. Though, a distinction shall be made among them: several of them wrote serious works of history, with few (compulsory) tributes to the regime and to Ceauşescu ${ }^{15}$. Other historians were "less scholarly", since 1) their researches were driven by a pre-established thesis - that means to invert the general logic of inquiry (observation $\rightarrow$ hypothesis $\rightarrow$ verification $\rightarrow$ thesis); 2) they caught the opportunity to follow the cultural-ideological tendencies supported by the regime (protochronism in the seventies, and in general nationalism in the seventies and the eighties); 3) they valued the party canon more than the standard, nullifying their own efforts to be considered as valuable historians by the domestic and international community. Despite all, it would be a useless task to give these historians a mark: they belonged to the same environment and have chosen to subscribe to the same cultural project. Nevertheless, the distinction is worth noting and challenges us to find out the individual trajectories among the "front of the historians" at Isisp.

\section{Theory (II): national historiographies between myth and history}

Being impossible to distinguish directly history-writing and (scholarly-shaped) propaganda and so to locate history on the imaginary line between scholarly writings and propaganda, I will proceed with an indirect comparison, introducing a third "reagent" element: myth. Since historians have been considered as myth-makers of national history-writing, I introduce a discussion on the distinction between history and myth, a literary genre which in our case is bordering with propaganda, since this latter is also a myth-maker, as history is.

What is the difference between history and myth? Correctly, Chris Lorenz pointed out that the traditional equations "history $=$ science" and "history $=$ myth" are outdated, because myths were built into the conception of scientific history: Leopold

source is represented by the fact that Ştefanescu considered only historians with a university degree in history, excluding the activists.

15 I.e., Marian Ştefan, redactor at popular history journal Magazin Istoric, indicated M. C. Stănescu, Ion Bulei, Constantin Botoran, Ion Calafeteanu, Viorica Moisuc, Vasile Niculae, Ion Mamina, Ion Alexandrescu, and Aurică Simion as valuable authors which published valuable books even in the seventies, when the party canon required nothing more than its fostering. ŞTEFAN, Marian, Trăite, Vazute, Auzite (1967-1989), Bucharest, Editura Oscar Print, 2004, p. 149. Those historians, after 1989, continued to write scholarly historiography, but their aspirations, passions, and ideas were finally free to take form without the normative ideological framework given by the Party. 
von Ranke and Wilhelm von Humboldt, founding fathers of the discipline, considered history as an interpretation and thus helped to construct the myths of the nation. According to Lorenz, the marginality of the history of historiography can be interpreted as a way to avoid any discussion on the discipline of history ${ }^{16}$, that ignores the possibilities to compare and evaluate other possible narratives. National history is thus «a specific form of historical representation that accompanied the formation of the nation-state or sought to influence the existing self-definitions of a national consciousness ${ }^{17}$. National myths have a performative function that set the boundaries of the community, forging images of the enemies and creating solidarity through rituals. Lorenz's conclusion seems to recall Hayden White's Metahistory: myth and history is the same thing, because history is nothing more than a form of narrative informed by ideology and seeking the status of "truth" 18 . Is there any limit to the Lorenz's conclusion «history $=$ narrative + ideology?». Following Lorenz, we shall conclude that history and propaganda is the same thing. Is it possible to distinguish them? Or does "everything goes", no literary or scholarly distinction between texts is operable?

I propose and introduce here a qualitative distinction between historiography that searches for historical truth, and historiography that propagate the truth, pretending to know it. Going back to the philology of the Latin terms, historia means narrative, knowledge, but also inquiry; propaganda, from the Latin propago (= to propagate), lacks in its meaning exactly the connotation of inquiry. We shall deduct that propaganda has 1) the task to spread the truth; 2) pretends to know the truth but does not require one to conduct an in inquiry in the search for it.

This hypothesis of inquiry offers a good model to interpret the essence of modern scholarly history-writing in Europe since its "early days" in the $19^{\text {th }}$ century until recent times. The close ties between the professional history discipline and political power are evident by several examples offered at the birth of the discipline in the $19^{\text {th }}$ century, when the not-too-innocent cohabitation of the two took place literally in the same premises..$^{19}$ Before the $19^{\text {th }}$ century most of the royal or duchies' libraries and archives

${ }^{16}$ LORENZ, Chris, Drawing the line: "Scientific" History between Myth-making and Mythbreaking, in BERGER, Stefan, ERIKSONAS, Linas, MYCOCK, Andrew (eds.), Narrating the Nation. Representations in History, Media and the Arts, New York-Oxford, Berghahn Books, 2008, pp. 35-55; p. 46.

17 BERGER, Stefan, Narrating the Nation: Historiography and Other Genres, in BERGER, Stefan, ERIKSONAS, Linas, MYCOCK, Andrew (eds.), op. cit., pp. 1-18, p. 5.

${ }_{18}$ WHITE, Hayden, Metahistory. The Historical Imagination in Nineteenth-Century Europe, Baltimore-London, The Johns Hopkins University Press, 1975.

19 PORCIANI, Ilaria, Networks of Power and Erudition, in PORCIANI, Ilaria, RAPHAEL, Lutz (eds.), Atlas of European Historiography, New York, Palgrave Macmillan, 2010, p. 16. 
were placed straight into palaces and castles, at complete disposition of the majesty, and were directed by humanists which were at the same time historians, archivists, and librarians. With the birth of modern nation-states, the history discipline started a process of professionalization, which meant, in times of nation-building historymaking, the scholarly justification for political thesis related to the defence of political power's will.

One example of this trend is offered by several Prussian historians who, on that regard, were exemplar: Leopold Von Ranke served loyally the cause of Prussia, while his colleagues Gustav von Schmoller and Heinrich von Treitschke supported the German Empire. The same goes for national archives, which were subject to strict political control - a tendency that persisted in twentieth century's totalitarian regimes. With the affirmation of democracies, the intellectuals became also the leading politicians: the already mentioned von Treitschke, disciple of von Ranke and successor of this latter at the Berlin University, funded the National-Liberal Party, and consequently his work as historian became aimed at delegitimizing other German states $^{20}$.

In Romania, two main figures can serve as examples of the two different steps that led to the emancipation of history from political power (but not from political aims): Mihail Kogălniceanu (1817-1891), nominated prime minister of the Union of the Danubian Principalities by his personal friend prince A. I. Cuza, saw his own activity as historian (and, more broadly, as humanist) as a prolongation of his political activity; Kogălniceanu is already a figure "in between" the two figures of historians I indicated: he survived to the end of Cuza's coup d'état, and was awarded by the former opposition with a place at the newly founded Romanian Academy, for his great scholarly successes and for the development of national education ${ }^{21}$. Vasile Urechia (1834-1901) fits in the second step of the process described: he was both state historian and politician in the new-born kingdom of Romania. His professional biography ${ }^{22}$ shows several similarities with Kogălniceanu's one, and particularly that his multiple "state service" was inscribed into a political national project; but his duties were of minor importance, compared to Kogălniceanu's ones.

\footnotetext{
20 Ibidem.

${ }^{21}$ CĂLINESCU, George, Istoria literaturi române. Compendiu, Bucharest, Litera International, 2001, pp. 79-81. ZUB, Alexandru, Mihail Kogalniceanu. Un architect al României modern, Iaşi, Institut European, 2005.

22 BURUIANĂ, Letiţia, ILIE, Zanfir, Contribuţia lui V. A. Urechia la dezvoltarea presei românesţi, in «Buletinul Fundaţiei Urechia», VII, 10, 2009, pp. 17-26.
} 
Maybe the difference between the founding fathers of the modern discipline and the contemporary historian, which moves in a standardized and professional environment, is that the formers are "politicians" and the latters are "professionals"? Did the profession of the historian change in the last century and a half for scholarly aims and relationships to political power? If we consider historiography under totalitarian regimes of the $20^{\text {th }}$ century, we would like to say that no, not much changed: in both historical periods, historians had to rely to a metanarrative canon. This trend was present both during the nation-building process and during communism as well. Historians had to satisfy the requests of political power, by writing pieces of scholarly literature that nowadays would be labelled as "propaganda".

It could be said that East European historians in communist times in partyfinanced institutions were in service ${ }^{23}$, but this is not enough. Far from any attempt to establish a comparison between $19^{\text {th }}$ century's historians and East European regimes' historians, I wish rather to stress that there are two characteristics which represent a strong continuity in historians' profession. Those are retraceable both in individual and in collective biographies of historians of the $19^{\text {th }}$ and $20^{\text {th }}$ century: 1 ) the need for resources 2) the participation in a political project in order to obtain recognition and success, both at personal and at institutional level. As a limitation, I shall state that what written here does refer exclusively to twentieth century's totalitarian regimes or, to adopt a "sociological" and simplifying category, but clear, the "theory" applies only where the two characteristics are present.

The distinction between scholarly-writing and propaganda is evident from the practices of history-writing. The distinction is both textual and extra-textual, but can be analysed by observing the game displayed between the imposition of an extraprofessional canon by a political regime onto the historians, and these latter' strategies in search for adjusting power's desiderata and professional standard.

The textual practices performed by Isisp historians are retraceable in their writings: their final products were the concretization of all their efforts and experience, summarizing their dedication towards the discipline, the hours spent studying other texts, listening and giving lectures, discussing with the colleagues. Their historiography embodied the theoretical perspectives and the methodologies of research applied. In this particular context, it is fundamental to remember that the texts are also the product of a self-censorship ${ }^{24}$ because most of the historians experienced the refusal of

\footnotetext{
23 See the introduction.

24 For example, Ion Bulei, researcher at Isisp between 1971 and 1989, was "sentenced" to a three-months stop from publishing. His "guilt" was the positive review he published on the
} 
being published for political reasons, or receiving advices to revise the text according to the ideology of the day ${ }^{25}$. At the same time, it is fundamental to remember that the tribute to the tenets of Marxism-Leninism was compulsory in each scholarly text. Historical materialism was the only possible theoretical approach allowed to history, so why should anyone loose time with studying bourgeoisies fallacious theories ${ }^{26}$ ? Dictatorship meant the monopoly of culture, which is given by the sum of the monopoly of financial resources, and the repressiveness of the totalitarian state. And that is why respecting the canon was mandatory for all those who had carrier expectations leading them in the sphere of culture.

Isisp historians had several privileges related to their professional activity and to the benefits derived from it, e.g., the possibility to publish regularly ${ }^{27}$ and to consult the archive of the Party, which kept the documents for its historians, asking for official request and performing political check to each and every other external willing to consult it $^{28}$. It also meant good salary, possibilities to access high class leisure facilities

journal Viaţa Studenteasca of Aurică Simion's book Preliminarii politico-diplomatice ale insurecţiei române din august 1944 [Cluj-Napoca, Editions Dacia, 1979], that presented interwar dictator Mihai Antonescu in a positive light. The punishment was intended to give the example to the other historians at Isisp. Gheorghe Zaharia said expressly, in front of all the researchers at Isisp: "This is wrong, you shall not do this". Source: Interview by the author with Ion Bulei; Bucarest, Romania; Febraury 12, 2013. An account of Simion's affaire is in PAVELESCU, Alina, Le Conducător, le Parti et le Peuple. Le discours nationaliste comme discours de légitimation dans la Roumanie de Ceauşescu (1965-1989), doctoral dissertation, Ecole doctoral de science politiques, Institut d'Etudes Politiques de Paris, February 2009, pp. 237-240.

${ }^{25}$ Some subjects were forbidden to historians, only the party could have written about them. One example is the topic of Besarabia: "You could refer to it only in the proper way, otherwise "you create a political problem", Muşat and Ardeleanu told informally to the Isisp historians». Source: Interview by the author with Ion Bulei; Bucarest, Romania; Febraury 12, 2013.

${ }^{26}$ Even if, since 1966, in the organizational structure of Isisp there was always a section dedicated to the study of «theoretical and methodological problems of historical research" [ANIC, CC al PCR, Secţia Cancelarie: 143/1966, 1-25; 11/1976, 12], this latter should be considered as a display of scholarly standard, since no relevant publication produced by it was published. Several, instead, are the testimonies of the presence of a theoretical approach informed by party official discourse. For example, during the seventies, Ceauşescu became the standard of reference for Marxist-Leninist theory. A good example of this trend is the manual for the compulsory course of Marxism-Leninism for all the university courses: see MUȘAT, Mircea, PETREANU, Nicolae, SÂRZEA, Ion, SMÂRCEA, Valentin, ZAHARIA, Gheorghe (eds), Probleme fondamentale ale istoriei patriei și partidului comunist român, Bucharest, Editura Didactică și Pedagogică, 1977.

27 The publishing plans were decided year by year. Nevertheless, publishing was anyway a difficult task full of compromises [see note 32 ].

28 The common practices of documents' request at Isisp archive are mentioned in STAN, Apostol, op. cit., p. 175. The enrollment in Isisp as a possibility to consult the archive and the library is mentioned in IONIŢA, Gheorge Ion, O viaţa, un destin, Istorii ştiute şi neştiute, Bucharest, Cartea Universitară, 2007, p. 61. 
as well as special medical clinics ${ }^{29}$, to travel abroad and, generally, the opportunity to stay close to the centre of the power ${ }^{30}$.

Some of those historians lost their interest in scholarly writings, becoming passionate and devoted canon-makers, and beyond, becoming for example keycharacters in the secret external relationships that characterized Romanian politics during the cold war; one example of this is Florin Costantiniu, who in the eighties lost his interest in historical research to follow and pursue personal power ${ }^{11}$. In addition, the fact that the Institute belonged to the Central Committee of the Party gave its historians a certain podestas (in opposition to auctoritas), that generated the fear in external historians to disagree even politely with Isisp historians' scholarly theses. Among these latter, there were both historians which did their job with passion and seriousness, like Ion Bulei, nowadays respected scholar, or dynamic and active supporters of the regime which served the cause of Romanian communism by doing their job as historian, like Georgeta Tudoran. But there were also dangerous and extremely vindictive persons, e.g., Mirca Muşat and Ion Ardeleanu, both at Isisp and in prominent positions at the Agitation and Propaganda Section, feared by each and every historian and the higher ranks of the party. Muşat and Ardeleanu asked expressly Isisp historians in lower ranks to write scholarly essays to be published in their names, justifying these requests as sarcină de partid (party obligations) ${ }^{32}$. And, finally, there were also "sphinx" activists/historians like Ion Popescu-Puţuri, who was extremely close to Ceausescu, but whose power's origin was mysterious for his colleagues ${ }^{33}$. It was mainly a matter of perception: Isisp historians had the shadow of their institute beyond them, and this influenced their professional relationships. All these advantages rent Isisp a very particular workplace, privileged but full of restrictions at the same time. Most of the recruitment was decided from above, which meant that no one could apply

\footnotetext{
29 Interview by the author with Ion Bulei [February 12, 2013].

30 Those advantages are mentioned both by Ion Bulei and by Şerban Papacostea [Interview by the author with Serban Papacostea; Bucharest, Romania, February 7, 2013].

31 «Very appreciated collaborator of our institution», and close friend of Ilie Ceauşescu [CNSAS, R 268425, Securitate report, October 15, 1986].

${ }^{2}$ Source: Interview by the author with Ion Bulei [Bucharest, February 12, 2013]. Bulei has been obliged to write for Muşat and Ardeleanu to obtain the approval for publishing his books and articles. According to Bulei, the same happened to Constantin Botoran, Ion Călăfeteanu, and Aurică Simion. See also CONSTANTINIU, Florin, De la Răutu şi Roller la Muşat şi Ardeleanu, Bucharest, Editura Enciclopedică, 2007, pp. 294-296.

33 None of mine informers could giving me neither a sketch of Popescu-Puţuri's character or position; nor can his familiar archive conserved at ANIC, fondul familial Popescu-Puţuri. Despite this limitation, his pivotal role in the conduction of Isisp has evidences in his conduction of Isisp from 1961 to 1989 , and is retrievable throughout the whole archive of Isisp.
} 
for the job34. But those who agreed to work there were required to perform the canon and strengthen it, some entrusted with the more crucial production of the canon metanarratives, some other historians (but also archivists and librarians) enrolled as craftsmen who produced basic working materials to propagate the intended truths.

In addition, a more subtle distinction can be operated on this kind of historywriting. All the textual and non-textual practices listed here embody implicitly a double canon of reading by the observer: one is the declared function; the other is the representative function. While, for example, scholarly texts should be written following a methodology, no one prevent these texts to be simply looking like scholarly writings, simply made up by references, bibliography, and other visible particulars. The same goes for persons and institutions: these latter and the writings they produced represented a function that the party needed. In the whole process of nationalcommunist history writing, the party, in constant search for legitimacy, pretended simply that the canon was respected, and that those historians were the hagiographists of the Party's successes. And its historians floated constantly, in their historiography as well as in the non-textual practices they performed, between the pole of propaganda and the one of scholarly standard; but all of them kept the appearance about the seriousness of their own work, and so always pretending to perform the declared function of their work, while adhering more or less to the representative one. There were both historians who have chosen to value their profession more than the adherence to activism's logics, but also the opposite was present in Isisp ${ }^{35}$. This balance changed: while in the sixties the appearances of scholarly writings were fulfilled by the majority of Isisp historians, in the mid-eighties the nationalcommunist canon rent the adherence to standard more difficult when not impossible ${ }^{36}$.

\footnotetext{
34 For example, Ion Bulei was invited to become researcher at the Institute in 1971 by his former mentor and supervisor Titu Georgescu, vice-director of Isisp. Georgeta Tudoran, which worked at Isisp since 1951 until its disbandment, was invited there by Mihai Roller, its first director. Source: interviews conducted by the author of this article with Ion Bulei [Bucharest, Romania, February 12, 2013] and with Georgeta Tudoran [Bucharest, Romania, March 16, 2013].

35 Exemplar is the case of SPĂLĂTELU, Ion, Scornicești. Vatră de istorie românească, București, Ed. Albatros, 1983. Spălătelu, researcher at Isisp. claimed that Scorniceşti, birthplace of Ceauşescu, was also the birthplace of the Dacians. Monica Lovinescu, journalist at Radio Free Europe, made «a very scathing review of this book, and the laughts were so loud and gigantic in all the country, that the guys [the Party] decided to retire the book from all bookshops and book libraries». Source: Interview by the author with Sorin Anthoi, Bucharest, Romania, February 3, 2013.

${ }^{36}$ Marian Ştefan's concern, in the mid-eighties, was that Isisp's popular magazine Magazin Istoric, very popular review in the sixties and the seventies, was having low sellings - most of the edited copies were returned: 'Everybody knows the cause, but no one says a word. «The special articles» occupy a larger space in the summary. Once, Magazin Istoric was not so concerned about «daily obligations». To all this, one should add also the articles of Puţuri...'. ŞTEFAN, Marian, Trăite, Vazute, Auzite (1967-1989), cit., p. 144.
} 
With methodologies of analysis traditionally used in historiography to analyse such milieu, one could obtain a quite colourful and lively series of diachronical images of this historiography, since huge amount of writings are available. Nevertheless, the vibrancy, the dynamics, and the motion are given to us by the constant reference to the historians' and the Isisp's biographies, whose elements narrate the extra-textual practices of history-writing. Among these latter, their whole professional life is considered, e.g., the acceptance into international occasions of scholarly communications, international conferences and committees. These practices are one with Isisp's "institutional" biography, e.g. the establishing of cultural exchanges, collaborations, and formal visits with other domestic and international institutions for the study of history.

Together, textual and extra-textual practices define the standard-to-be, which is the result of the constant and recurring performance that the historians practiced over the canon and the primary sources of history-writing. In this regard, it is important to specify that we cannot differentiate between the historiographical standard which the Isisp historians rely on and the new one which is the result of their performance: to do this, we should start our narration from 1951, when the Institute was founded, and sum up the difference of the new Stalinist historiography with what preceded it. 37 But it is sufficient to clarify that, at the dawn of Isisp, compulsory theses about the greatness of Socialism and Soviet Union were applied with historicist and determinist approach, and until the mid-sixties the situation remained the same ${ }^{38}$.

But one more canon and one more standard were present in the process of nationalcommunist history-writing: the nationalist metanarrative canon and the scholarly professional standard. The nation was the ubiquitous subject of historiography, prior to the advent of communism to power, and since the mid-sixties the usage of traditional sources which constituted the national discourse in the $19^{\text {th }}$ century and in the interwar era was re-established. As in the $19^{\text {th }}$ century, the subjects were imposed by the political power, which gave resources to the historians, while the correct scholarly interpretation of the sources was competence of the historians, which resurrected them as vestiges of the past. This meant the depiction of a historiographical standard, that

\footnotetext{
37 A work done by IACOB, Bogdan Cristian, Stalinism, Historians, and the Nation: HistoryProduction under communism in Romania (1955-1966), Budapest, doctoral dissertation in History, Central European University Publishing, 2011.

38 PLESA, Liviu, "Mihail Roller si "stalinizarea" istoriografiei romaneşti», in Annales Universitatis Apulensis - Series Historica, 10, 1/2006, pp. 165-177.
} 
the party would have swallowed only to regurgitate a new reinforced national(commun)ist canon 39 .

The second standard historians had to rely on was the international contemporary standard which influenced the construction of the history-writing discourse in all its aspects and practices, from text-editing to scholarly communication. It was this standard which provided most of the time the border to which the Party historians refused to follow the directives of a despotic and limitless political power. This standard was defined and defended openly and strongly, for what concerns Romanian historywriting, mainly by domestic historians which refused to give up their professionalism ${ }^{40}$, but also by Western commentators and critics ${ }^{4}$. Worth mentioning are also those historians who, without too much clamour, opted for less political subjects, which were also more free in their discursive construction.

The international scholarly standard is the formal minimum requirements (textual practices) that literature should fit to be considered scholarly ${ }^{42}$. Archival field-works, conferences and visiting positions abroad were the extra-textual practices set. The obsession of the party to show and display domestically and abroad a pretended primacy in all fields, including historical research, created, after all, a tension towards adherence to international standards.

The last mandatory category that the historians were forced to follow was the metanarrative canon imposed by the party, which included the aforementioned nationalist canon and the Marxist-Leninist framework, and which was partly, and ironically, elaborated by the activists and historians, with heavy intermissions by Ceauşescu's speeches. This canon is the metanarrative, visible in all the historical texts produced. It was normative in the message conveyed in the texts produced by the Isisp historians, but also embodied in the practices of their professional positions.

To resume, the work of Isisp historians was extremely normative: they had to follow the metanarrative canon imposed by the party, the nationalist canon present in $19^{\text {th }}$

39 The unsustainability, on the long run, of this canon-standard play, is perfectly exemplified by the vicissitudes of the treaty of History of the Romanians. Wanted at all cost by the Party since the mid-seventies, it was never released (also) because of the changes in the metanarrative canon and the adoption of a protochronist stance by the regime. VERDERY, Katherine, National Ideology under Socialism, cit., p. 151.

40 The most touching cry in defence of history discipline is GEORGESCU, Vlad, Politică şi Istorie, cit. Written in 1977, the volume was published for the first time in 1980, in Germany.

${ }^{41}$ Verdery dedicated her monograph (dated 1991) to the memory of 'David Prodan, and to all those who, like him, said "No!" - some even with their life'. VERDERY, Katherine, National Ideology under Socialism, cit., p. V.

${ }^{42}$ In this sense, a good example is offered by the books written by Isisp historians who were translated and published in foreign countries. Those publications met the international scholarly standard as intended by the Party officers. 
century historiography, the standard elaborated by themselves, and the international scholarly standard. Being them on the borderline between party activists and scholars, their professional lives was a constant challenge between being and appearing as scholars.

The choice to focus our attention on the aspect of national- and nationalistnarrative and the environment which produced it is not dictated by the vast amount of literature about the Romanian nation produced by Isisp. On the contrary, it is dictated by the fact that communist cultural politics, including Stalin's era ones, represented an attempt to create a cultural revolution which in the first moment embodied only few elements of national discourse, inserted in a Marxist-Leninist discourse. As the years went by, those few elements became the core of a vast and omni-comprehensive cultural project whom élan vital still appealed to Leninism, powered by the strong order created by socialist realism43. It must be taken in consideration that, before the raise of national values in after-Stalin contests, Marxist-Leninist ideology actually had a pivotal role in forging cultural politics. Marxism-Leninism, revolutionary per se, intended to cleanse old bourgeois and reactionary values, for building up future society on a new set of values of emancipation, equality, and dictatorship of the proletarians. With these pretences, whole cultures and persons were erased, and the new world should have been built from a tabula rasa ground.

This characteristic applies to Romanian communism's cultural politics but for other East European communist countries as well, were these latter into the Warsaw pact or not. This is the persistent shadow that Stalin casted upon part of Europe. At the light of this consideration, it is not incredible to think that the same institute that used to elaborate doctrinal texts on Marxism-Leninism became just few decades after the place where the cult for the nation and its leader were being elaborated. This was due to the fact that Isisp was, mainly, a propaganda institute; but this is not enough to liquidate the whole historiography only as producer of propaganda, nor to analyse a whole corpus of historiography and giving to it patent of "nationalist" or of "nationalcommunist”. But this, far from being yet another history of nationalist cultural products in communist countries, is a history of those who performed the metanarrative canon into a scholarly form, caught in their milieu, across a given time span.

${ }^{43}$ See KOTKIN, Stephen, Magnetic Mountain. Stalinism as a Civilization, Berkley, University of California Press, 1997, pp. 355-365. 


\section{Towards a new methodological approach}

In totalitarian regimes, academia has to deal with a unique founder, the Party-State, which is qualitatively more normative than financiers in democratic contexts: it may pretend the use of sources, the study of certain subjects, it may follow unwritten and inscrutable logics finalized at stopping or changing projects and researches - with any kind of excuse. And it pretends that only a certain kind of knowledge is developed.

For these reasons, the mere analysis of written historiography is not enough to understand a whole general trend of history-writing. Rather, the interplay of written historiography, the collective biography of the institution I consider (Isisp) and the personal biographies of its historians become necessary parts to answer to the initial question. The approach accounts the performances by the historians in history-writing, consider the texts produced, the norms dictated by political power, the research plans, and the biography of the Isisp and of its historians. Starting from the outcomes of the works of the historians - namely, historiography - it is possible to proceed to the deconstruction of the practices of writing history, and to catch the historians in the act of writing the history of the national-communist nation, trying to make order between the complexities of their profession, divided between loyalty to their duties as historians of the Party and their professional aim to publish valuable historiography. As standpoint, I must state that I do not consider individual or collective biographies as coherent narratives, because the participation to a political project and the need for resources can easily intermix or be confused by the observer with other trajectories, given that human intentions are sometimes inscrutable, and/or because of the absence of documents and testimonies about a given action.

The methodology of traditional collective biography, focused on a small group and enriched by the 'French prosopography' methodology44, can contribute to create deeper understanding of these practices, and of the dynamic relationships between their protagonists 45 . As Donald Broady explains, the first aim of the researcher must be

44 The whole work of Pierre Bourdieu has been considered by Donald Broady as a new kind of prosopography, namely 'French prosopography' or 'Bourdieuan prosopography'. Broady has defined the Bourdieu's methodology as «the study of individuals belonging to the same field [...] based on comprehensive collection of data [...] on these individuals, [...] their position in the social space and in the field»; and, most important, «the main object of study is not the individuals per se but rather the history and structure of the field». In BROADY, Donald, «French Prosopography. Definition and suggested readings», in Poetics, 30, 5-6/2002, pp. 381385, pp. 381-382.

45 Ibidem. 
directed neither to individuals nor to their interactions, but rather «to the history and structure of the field itself», which gives meaning to the actions of the individuals ${ }^{46}$. The Bourdieuian notion of field, in fact, defines people struggling over something, and is taken for granted that the quest for hegemony is what leads the intentions and wills of the protagonists, and thus the history of the collective considered.

A collective biography structured in this way shares similarity with the point of departure of actor network theory, which considers the social structure made of individuals and organizations ${ }^{47}$. According to this theory, human behaviour and social processes cannot be explained by the attributes of individuals or collective actors. What counts, here, is the position occupied in the network, the relational data

which relate one agent to another and so cannot be reduced to the properties of individual agents themselves. Relations are not the properties of agents but of systems of agents; [...] network analysis consists of a body of qualitative measures of network structure ${ }^{48}$.

Thereby, it is possible to write the collective biography of Isisp once several examples will have shown that the method which includes an integrated analysis of the narratives, of the individual biographies of the historians and of the collective biography of the Institute is a useful instrument a) to clash the presumed borders between literary and scholarly activities; b) to demonstrate that several trajectories are performed in the single act of history-writing (the deeds of political power, the scholarly in practice) and that only in this way this historiography is understandable; and, c) to create a new and more nuanced understanding of whole East European national-communist history-writing; if, before proceeding to write a prosopography of the Isisp a), b), and c) are not taken into account and demonstrated - it would be just another collective biography, written with nothing but a historicist-factual perspective.

\footnotetext{
${ }^{46}$ Ibidem, p. 383 .

47 Defined as "nodes". LATOUR, Bruno, Reassembling the Social. An Introduction to ActorNetwork-Theory, Oxford, Oxford University Press, 2005. The most striking definition, even if in metaphor, is given by Latour: the actor network theory «is nothing but an extended form of Machiavellianism». Ibidem, p. 252.

48 SCOTT, John, Social Network Analysis. An introduction, London, Sage, 200o, pp. 9-10; quoted in KEATS-ROHAN, Katherine (ed.), Prosopography. Approaches and Applications. A handbook, Oxford, University of Oxford, 2007, p. 23.
} 


\section{Conclusion: Setting the standard as a dividing line between propaganda and scholarly writing}

It is not possible to distinguish scholarly historiography and propaganda. Trying to locate history on an imaginary line between these two literary genres, they appear to be the same thing, being both informed by ideology and aiming at the status of truth. The main point of my article is to introduce a new methodology, supported by a theoretical framework, which rend the distinction between the two understandable. The method consists in analysing one field of historiography, in this case Romanian nationalcommunist historiography, and considers what is beyond the texts, namely the professional lives of their writers and the organizational history of their institution.

Analysing the practices of history-writings it results that, in totalitarian systems, the writing of history is made though time by the interplay of a metanarrative canon imposed by political power and by a scholarly standard that the historians elaborate (aim at creating coherence for the historians in their job and for political power's compulsory theses). The closed and vertical systems of East European communist historiographies were questioned and confronted by Western and dissident scholars abroad, and for this reason its historians had to produce an international standard. And, in addition, the national pasts were all but dead, and its historians had to refer to it.

The setting of a standard was a necessity for Isisp historians at least since the end of Soviet Stalinism: they had to perform a new, national-communist metanarrative canon, being able to do it scholarly. It can be added, in conclusion, that this standard did not help at all in fulfilling their aim to be accredited nationally nor internationally. The historiographical standard became a mere auxiliary for producing propaganda in form of scholarly writing. On December 1989, it was obvious for whoever, scholar or not, that Isisp would not have lasted long. In February 1990 it was closed, and only those historians which had demonstrated to be serious researchers also during the party canon dictatorship found new positions in research and educational environment of democratic Romania. 


\section{* The autor}

Francesco Zavatti (1982) is Ph. D. candidate in history at the Baltic and East European Graduate School at Södertörn University, Sweden. In 2010, he graduated magna cum laude in history at the University of Modena and Reggio Emilia, Italy, with a thesis on Historiography and nationalism in Ceausescu's Romania. In the period 2008-2011, Zavatti collaborated in educational and publishing projects at the Modena History Institute, Italy. In 2010 he was awarded a scholarship from the Modena Savings Bank Foundation (Italy) in order to conduct historical research on the National Disabled Ex-Servicemen Association, resulting in the publication of a monograph and a public exhibition. In 2012, Zavatti received a scholarship from the Helge Axelsson Johnsons Foundation (Sweden) supporting his archival researches in Eastern Europe for his doctoral dissertation. He published Mutilati ed invalidi di guerra. Una storia politica. Il caso modenese (Milano, Unicopli, 2011) and Comunisti per caso. Regime e consenso in Romania durante e dopo la Guerra fredda (Milano, Mimesis, 2014).

URL: < http://www.studistorici.com/progett/autori/\#Zavatti >

\section{Per citare questo articolo:}

ZAVATTI, Francesco, «Beyond the iron curtain of historiography, between party canon and scholarly standard A theoretical and methodological approach to the analysis of East European national-communist historiographies: the case of Romania», Diacronie. Studi di Storia Contemporanea, 29/09/2014,

URL:< http://www.studistorici.com/2014/09/29/zavatti_numero_19/ >

\section{Diacronie Studi di Storia Contemporanea of www.diacronie.it}

Risorsa digitale indipendente a carattere storiografico. Uscita trimestrale. redazione.diacronie@hotmail.it

Comitato di redazione: Jacopo Bassi - Luca Bufarale - Elisa Grandi - Deborah Paci - Fausto Pietrancosta - Matteo Tomasoni - Luca Zuccolo 